\title{
UNIVERSITY OF PENNSYLVANIA RADIOCARBON DATES V
}

ELIZABETH K. RALPH and ROBERT STUCKENRATH, JR.

Department of Physics and University Museum, University of Pennsylvania, Philadelphia 4, Pennsylvania

\section{INTRODUCTION}

In conformance with the request of the editors, ages in this date list have been calculated with the Libby half life value, $5568 \pm 30 \mathrm{yr}$. We should like to mention, however, that the "effective" and, possibly, the true value may differ from this by several hundred years (see discussion by Kohler and Ralph, 1961). The measurements of samples of known age indicate that the "effective" half life value is close to $5800 \mathrm{yr}$, except for specific recent periods.

Our standard samples for calibration are 110-yr-old oak samples. These, when corrected for age, have $\mathrm{C}^{14}$ contents equal to $95 \%$ of the NBS oxalicacid standard. The differing fractionation effects as reported by Craig (1961) in the processing of oxalic acid have negligible bearing on our age calculations since we have continued to use the wood standard. Variations, due to fractionation effects, of our wood samples are being determined presently by the measurement of $\mathrm{C}^{13} / \mathrm{C}^{12}$ ratios.

All samples have been pretreated with $\mathrm{HCl}$, and some, as noted in the date list, have also been treated with $\mathrm{NaOH}$ for the removal of possible humic acid contaminants. All samples were counted at least twice.

The B.P. dates are calculated from A.D. 1950. The samples were measured in 1959 and 1960.

\section{SAMPLE DESCRIPTIONS}

I. GEOLOGIC SAMPLES

\section{A. Eastern United States}

\section{P-304. Philadelphia "Subway Tree"}

Wood from stump of Taxodium distichum, Philadelphia, Pennsylvania ( $39^{\circ} 58^{\prime} \mathrm{N}$ Lat, $75^{\circ} 09^{\prime} \mathrm{W}$ Long). Stump was one of several found standing upright $38 \mathrm{ft}$ below street surface, $10 \mathrm{ft}$ below sealevel, during subway excavations at 8th and Locust Streets. Coll. 1931 and subm. 1956 by H. G. Richards and E. T. Wherry, Univ. of Pennsylvania, Philadelphia, Pennsylvania (Richards, 1931, 1960). Comment: trees believed to belong to interglacial Cape May formation of Sangamon age.

\section{ARCHAEOLOGIC SAMPLES}

\section{A. Syria}

P-354. Jerf Ajla (Heifer Cave), Syria

Charcoal and dirt from two samples from Jerf Ajla $\left(34^{\circ} 37^{\prime} \mathrm{N}\right.$ Lat, $38^{\circ}$ $12^{\prime}$ E Long), in desert, $12 \mathrm{~km} \mathrm{NW}$ of Palmyra, Syria. Sample A-2 consisted of small pieces of charcoal in fine ash or dirt from intrusive hearth; sample 
A-3 consisted of small pieces of charcoal in light yellow dirt. This is a complex stratum of brown lenses in yellow soil; implements are found mostly in the yellow. Coll. 1955 and subm. 1956 by C. S. Coon, Univ. Mus., Univ. of Pennsylvania (Coon, 1957). Comment: samples too small to permit $\mathrm{NaOH}$ pretreatment. Compare with samples from older levels of this site as dated by New Zealand (Sample A-8: NZ-76, 43,000 \pm 2000; Sample C-8: NZ-77, $18,000 \pm 200$, and NZ-78, 19,800 \pm 300 , New Zealand III) .

\section{B. Mediterranean Series}

Most of the dates in these series were published previously in Am. Jour. of Archaeology (Kohler and Ralph, 1961). In that article, two ages were reported for each sample-one calculated with an "effective" half life value of $5800 \mathrm{yr}$ (as determined by measurements of samples of known age), and the other with the Libby 5568 value. The reader is referred to the original article for a fuller explanation of the change. Dates for representative samples, as calculated with the 5800 half life, are closer to archaeological expectations. The sites reported in Am. Jour. Archaeology and repeated here are: Hacilar, Beycesultan, and Gordion in Anatolia; and Eutresis, Lerna, Pylos, and Chios in Greece.

\section{Hacilar series, Turkey}

Hacilar $\left(37^{\circ} 35^{\prime} \mathrm{N}\right.$ Lat, $30^{\circ} 05^{\prime} \mathrm{E}$ Long), is located $25 \mathrm{~km} \mathrm{~W}$ of Burdur in SW Turkey. Excavations were begun in 1957 by the British Inst. of Archaeology at Ankara under field director James Mellaart. Levels I to V (numbered from top downward) have been dated through ceramic and other parallels as Early Chalcolithic, while Levels VI to IX are considered Late Neolithic. Coll. 1958 and 1959 by J. Mellaart; subm. 1959 by G. R. Edwards, Univ. Mus., Univ. of Pennsylvania (Kohler and Ralph, 1961).

\section{P-314. Level IX, Late Neolithic $\quad \mathbf{7 3 4 0} \pm 94$}

Charcoal fragments from a rubbish deposit from the bottom or lowest Neolithic level. Comment: sample not necessarily representative of either extreme of the level. Half of the sample was given usual acid pretreatment, while other half received additional $\mathrm{NaOH}$ pretreatment; the difference in age (189 $\pm 184 \mathrm{yr}$ ) is of no significance, and four counting runs were averaged.

\section{P-313A. Level VI, Late Neolithic}

$\mathbf{7 3 5 0} \pm \mathbf{8 5}$

Charcoal from a hearth in use before a destructive fire. This is the upper Neolithic level and may date the end of Level VI. Comment: compare British Museum date for burnt post or beam from Level VI of a different area of this site (BM-48, $7550 \pm 180 ;$ British Museum II). The difference in age may be that between construction at the beginning of Level VI (BM-48) and its destruction (P-313A), or there may be more than one phase of Level VI involved. Half of this sample was given usual acid pretreatment (P-313, $7150 \pm 98)$, while other half received additional $\mathrm{NaOH}$ pretreatment (P-313A, $7350 \pm$ $85)$; the difference in age $(203 \pm 122 \mathrm{yr}), 1.6$ times its standard error, is considered significant, and the age of P-313A is quoted here. 
P-316. Level II, Early Chalcolithic

$7170 \pm 134$

Charcoal from a roof beam, Area N, Room 4, of the settlement. Sample may date construction of the second phase of Level II (IIb). Comment: many small rootlets noted, all visible ones removed. $\mathrm{NaOH}$ pretreatment.

P-315. Level Ia, Early Chalcolithic

$6990 \pm 121$

Charcoal from a roof beam, Room 5 of the fortress, probably from construction of Level Ia (top level). Comment: many small rootlets noted, all visible ones removed. Half of sample received usual acid pretreatment, while other half received additional $\mathrm{NaOH}$ pretreatment; difference in age was not significant, and four counting runs were averaged.

\section{Beycesultan series, Turkey}

Beycesultan ( $38^{\circ} 15^{\prime} \mathrm{N}$ Lat, $29^{\circ} 44^{\prime} \mathrm{E}$ Long), is located in the upper Maeander River Valley, $5 \mathrm{~km}$ S of Çivril, Turkey. Excavations, begun in 1954, were sponsored by the British Inst. of Archaeology at Ankara under the direction of Seton Lloyd. Coll. 1958 by J. Mellaart, assistant to the director; subm. 1959 by G. R. Edwards (Kohler and Ralph, 1961).

\section{P-297. Level XXVIII, Late Chalcolithic}

$4690 \pm 62$

Charcoal from Sounding SX, from middle of Late Chalcolithic sequence. Comment: half of the sample was given usual acid pretreatment, while other half received additional $\mathrm{NaOH}$ pretreatment; difference in age was not significant, and three counting runs were averaged.

P-298. Level XXXVI, Late Chalcolithic

$4960 \pm 58$

Charcoal from Sounding SX, from 5th building level above virgin soil, Late Chalcolithic sequence. Comment: half of sample was given usual acid pretreatment, while other half received additional $\mathrm{NaOH}$ pretreatment; difference in age was not significant and four counting runs were averaged.

\section{Gordion series, Turkey}

Gordion ( $39^{\circ} 45^{\prime} \mathrm{N}$ Lat, $31^{\circ} 55^{\prime} \mathrm{E}$ Long), on the Sangarius River, $70 \mathrm{mi}$ $\mathrm{SW}$ of Ankara, Turkey, is the site of a Phrygian kingdom that fell during the Cimmerian barbarian invasion of the early 7 th century в.c. The City Mound (the town) was rebuilt during the period of the Persian Empire, and contains strata dating from Chalcolithic to Galatian Periods. Burials in earth tumuli, so far excavated, date from earliest-740 B.C.--through Hellenistic. Excavation of the site was begun by the Univ. Mus., Univ. of Pennsylvania, in 1950 under the direction of R. S. Young. Coll. and subm. by Young (Pennsylvania III; Kohler and Ralph, 1961).

\section{P-363. Tumulus W}

$\mathbf{2 7 2 0} \pm \mathbf{5 4}$

Wood slivers and strips, fragments of roof beam. Pre-Cimmerian Phrygian tumulus. Estimated age: 2700-2660 B.P. Comment: larger pieces showed signs of rot; considerable dust present, either ashy material or rotted wood. See General Comment below. 
P-275. Tumulus MM (Royal Tomb)

Acer pseudoplatanus, part of top of 3-legged table found collapsed on floor of tomb. Pre-Cimmerian Phrygian tumulus. Estimated age: 2685-2660 в.P.

P-99. City Mound

$2660 \pm 118$

Charcoal lumps found in red-polished pitcher on floor of $\mathrm{N}$ room of burnt Phrygian house. Pre-Cimmerian habitation level. Estimated age: $2660 \pm$ 25 B.P.

P-221. Tumulus $S_{1}$ Chamber

$2660 \pm 62$

Wood, reddish in color, very light in weight. Post-Cimmerian Phrygian tumulus. Estimated age: 2660-2560 B.P.

\section{P-352. Tumulus H Cemetery, Burial at U $\quad 2390 \pm 61$}

Wood, red and crumbling. Iron Age burial, no pots or other finds for dating. Estimated age: 2710-2460 B.P.?

P-222. Tumulus H Cemetery $\quad \mathbf{2 4 8 0} \pm 48$

Charcoal and wood chips. Burial of Persian period. Estimated age: 2510 \pm 25 B.P.

\section{P-256. Tumulus I, Cremation}

$2510 \pm 61$

Charred wood (bark and twigs) from pyre. Burial of Persian period. Estimated age: $2485 \pm 25$ в.P.

P-257. City Mound

$2120 \pm 59$

Large lumps of clean charcoal. Hellenistic-Galatian habitation level. Estimated age: $2160 \pm 25$ в.P. Comment: sample taken from outer 10 rings of piece showing 40 to 45 growth rings, including center.

General Comment on Gordion series: several samples of wood from Gordion yielded unexpectedly old dates; some, judging from tree-ring analyses, could be inner wood and therefore may not date the building of the structures from which they came. They are arranged here in chronological order according to the excavator's estimates of their dates. These notes and a general commentary, as reported in Kohler and Ralph (1961, p. 362-363), are repeated here.

P-133 (2939 \pm 122 , Pennsylvania III) came from Tumulus MM which contained the tomb datable 740-700 B.C., and was wood from a squared beam of Pinus nigra pallasiana used for the inner wall of the tomb chamber. The sample was taken from the outer surface of the beam, but it is suspected that these trees grew large enough for a hundred years or so of growth rings to have been removed in the shaping of this squared beam by the builders of the tomb. The $\mathrm{C}^{14}$ date obtained was $981 \pm 122$ B.C.

P-358 (2890 \pm 87 ; discussed by Kohler and Ralph, 1961), from Tumulus $\mathrm{N}$, was a sample from among the beams lining the burial chamber. The tomb has a possibly long range of date, as the contents were not very distinctive, but should fall between 700 and 600 B.c. The wood was reddish and in crumbling condition. The $\mathrm{C}^{14}$ date obtained was $940 \pm 87$ в.c. 
P-220 (2750 \pm 49 ; discussed by Kohler and Ralph, 1961) was collected in 1951 from inside Tumulus $J$ (datable ca. $650 \pm 50$ в.c.) and could have come from either the floor or a collapsed roof beam of the chamber. The wood was dry and crumbled into chips, and a few pieces were slightly charred; several rootlets were removed. The $\mathrm{C}^{14}$ date obtained was $800 \pm 49$ в.с.

P-356 (2920 \pm 45 ; discussed by Kohler and Ralph, 1961) was a sample of crumbling red wood from the chamber of Tumulus $\mathrm{S}_{2}$ with an estimated date of $650-550$ в.c. according to R. S. Young. The $\mathrm{C}^{14}$ result was $970 \pm 45$ B.c.

From the Persian level on the City Mound three samples, P-353, P-223, and P-218, were submitted. All were from buildings which must have been constructed in the interval 540 to 500 в.с. P-353 ( $2910 \pm 53$; discussed by Kohler and Ralph, 1961) consisted of three large pieces from the burned threshold of Building A, constructed ca. 540 B.c. It yielded a $\mathrm{C}^{14}$ date of $960 \pm$ 53 B.c. P-223 ( $2830 \pm 45$; discussed by Kohler and Ralph, 1961) came from the Persian Gateway, and consisted of powdery red wood from inside the "leaning tower" of this construction. The $\mathrm{C}^{14}$ date was $880 \pm 45$ в.c. P-218 (2900 \pm 51 ; discussed by Kohler and Ralph, 1961) was a piece of wood from the fallen doorpost in the Gateway and consisted of a portion of a $\log$, partially powdery. The $\mathrm{C}^{14}$ date was $950 \pm 51$ в.C.

For most of the above samples, several portions were processed, and for all except P-358, the portions were counted several times. This additional processing and extra care in counting was performed before it was realized that the growth rings in these woods were exceptionally narrow. Since these samples consisted of crumbling dry wood or of charcoal of indeterminate structure, cross sections of Juniperus drupacea were examined. Two large sections, diam ca. $40 \mathrm{~cm}$, from Tumulus MM, contained at least 375 and 620 growth rings. One small section,diam $15 \mathrm{~cm}$, from the rubble that supported the Persian Gate construction, contained 140 growth rings. (Juniperus is not ideal for dendrochronological purposes, but these sections were the only ones available.) It has not yet been demonstrated that these rings represent annual growth. However, the erroneously old $\mathrm{C}^{14}$ dates indicate that this assumption is plausible. On the basis of $\mathrm{C}^{14}$ dates previously reported for Tumulus MM, it now seems reasonable to assume that these well-preserved sections of Juniperus were representative of the wood used at Gordion during this time interval. For example, the $\mathrm{C}^{14}$ dates for the Juniperus drupacea (P-127, $2701 \pm 90$, Pennsylvania III), the outer part of an unfinished log, for textiles (P-128, $2631 \pm$ 90, Pennsylvania III), and for food (P-134, $2606 \pm 117$, Pennsylvania III) are in reasonable agreement with the estimated archaeological date of 725 B.c., whereas that for a squared beam of the inner wall (which consisted of Pinus nigra pallasiana, P-133) was $981 \pm 122$ в.c. Examination of the construction of this tomb has revealed that it was built within a short period of time; although there are two walls, inner and outer, the outer layers of their beams should be contemporaneous.

It therefore seems reasonable to conclude that seven wood samples (P-133, $218,220,223,353,356$ and 358) antedated the cutting of the trees by several hundred years, and are not representative of the dates of the structures. The 
slow growth of Juniperus may also indicate that the forests at Gordion were already marginal in Phrygian times, and might have died out naturally even if they had not been cut extensively.

\section{Eutresis series, Greece}

Eutresis ( $38^{\circ} 17^{\prime} \mathrm{N}$ Lat, $23^{\circ} 09^{\prime} \mathrm{E}$ Long), is located in Boeotia, SW of Thebes, Greece. This excavation, supplementary to that of H. Goldman in 1924-1927, was conducted by J. L. and Elizabeth Caskey for the Am. School of Classical Studies at Athens in 1958 (Caskey, 1960; Kohler and Ralph, 1961). Coll. 1958 from stratified deposits by J. L. Caskey; subm. 1960 by G. R. Edwards.

P-307. Early Helladic I (Eutresis Group III) $\quad 4440 \pm 64$

Charcoal from habitation deposits, Trench A, West, $1.17 \mathrm{~m}$ above datum. Comment: $\mathrm{NaOH}$ pretreatment.

P-306. Early Helladic I (Eutresis Group IV) $\quad 4450 \pm 75$

Charcoal from habitation deposits, ca. $1.5 \mathrm{~m}$ above datum. Comment: $\mathrm{NaOH}$ pretreatment.

P-317. Early Helladic II (Eutresis Group VIII) $4210 \pm 64$

Charcoal from floor deposit in House L, Room III, ca. $2.5 \mathrm{~m}$ above datum.

\section{Lerna series, Greece}

Lerna ( $37^{\circ} 32^{\prime} \mathrm{N}$ Lat, $22^{\circ} 45^{\prime} \mathrm{E}$ Long), is on the $\mathrm{W}$ shore of the Argolic Gulf, opposite Nauplia, Greece. The site is beside the Lernaean Spring, at the modern village of Myloi. It was occupied during the Neolithic and Bronze Ages and, to some extent, in later times. Excavations were conducted by the Am. School of Classical Studies at Athens from 1952 to 1958 under the direction of J. L. Caskey. Coll. by Caskey from levels assigned on stratigraphic evidence to Early and Middle Bronze Ages; subm. 1960 by G. R. Edwards (Kohler and Ralph, 1961).

P.321. Late Early Helladic II (Lerna Period III) $3940 \pm 68$

Charcoal from floor of burnt room, CA, in Trench GK, $4.7 \mathrm{~m}$ above sealevel. Precedes House of the Tiles. Coll. 1954. Comment: half of sample was given usual acid pretreatment, while other half received additional $\mathrm{NaOH}$ pretreatment; difference in age was not significant, and five counting runs were averaged.

\section{P-312. Late Early Helladic II (Last Phase, Lerna Period III)}

$3840 \pm 72$

Charcoal from burnt debris in Corridor IV, House of the Tiles, Area B. Coll. 1957.

P-318. Late Early Helladic II (Last Phase, Lerna Period III)

Charcoal from burnt debris (presumably woodwork) in Corridor IV near Door E, House of the Tiles, Area B. Coll. 1954. 


\section{P-319. Late Early Helladic II (Last Phase, Lerna Period III) $3980 \pm 66$}

Charcoal from burnt debris near E end of Corridor IV, House of the Tiles, Area B. Coll. 1954. Comment: sample possibly contaminated by rubbish of Lerna Period IV.

P-320. Late Early Helladic II or Early Early Helladic III (Late Phase, Lerna Period III or Early Phase, Lerna Period IV) $3930 \pm 65$

Charcoal from burnt debris over NW part of House of the Tiles, ca. $1 \mathrm{~m}$ above floor, Area BB. Coll. 1954. Comment: sample probably contemporary with the building, but possibly affected by activity in the first phase of Lerna Period IV. NaOH pretreatment.

P-300. Early Early Helladic III (Early Phase, Lerna Period IV) $3870 \pm 61$

Charcoal from Area BC, W of House of the Tiles, just above burnt debris of the building. Coll. 1957. Comment: $\mathrm{NaOH}$ pretreatment.

P-299. Early Helladic III (3rd Building Phase, Lerna Period IV) $3750 \pm 97$

Charcoal from Area BH, a rubbish pit (Bothros 8), containing refuse and broken pottery. Coll. 1958. Comment: $\mathrm{NaOH}$ pretreatment.

\section{P-303A. Middle Helladic (1st Phase, Lerna Period V)}

$3750 \pm 112$

Burnt material in large storage jar in Room 45, Area BE. Coll. 1956. Comment: half of sample was given usual acid pretreatment (P-303, $3520 \pm$ 59), while other half received additional $\mathrm{NaOH}$ pretreatment (P-303A, 3750 $\pm 112)$; difference in age $(231 \pm 119 \mathrm{yr}), 1.9$ times its standard error, is considered significant, and the age of P-303A is quoted here.

\section{Pylos series, Greece}

Pylos is located on a hill called Epano Englianos $\left(37^{\circ} 05^{\prime} \mathrm{N} \mathrm{Lat,} 21^{\circ} 45^{\prime}\right.$ E Long), $4 \mathrm{mi} \mathrm{N}$ of Navarino Bay in Western Messenia. Excavations begun in 1952 are being conducted by the Archaeol. Exped. of the Univ. of Cincinnati in cooperation with the Greek Archaeol. Service. The Palace seems to have been built and occupied in the period when pottery of Late Helladic, or Mycenaean IIIB was in use. At the present stage of excavation, the site comprises two administrative and residential buildings as well as a workshop and a wine magazine. The southwestern unit was probably erected first and the main central structure soon thereafter. All parts of the palace, as well as the lower town, were destroyed by fire at the end of Mycenaean IIIB. Samples from the main building, workshop, wine magazine and adjacent areas coll. 1958 and 1959 by C. W. Blegen and M. Rawson; subm. 1959 by G. R. Edwards (Kohler and Ralph, 1961).

P-254. Southeast of Wine Magazine

$3450 \pm 62$

Charcoal, possibly from earlier building cut through by foundations of 
wine magazine, from Area MZ-6. Comment: estimated to be earlier than the palace. $\mathrm{NaOH}$ pretreatment.

P-270. Southeast of Wine Magazine

$\mathbf{3 3 4 0} \pm \mathbf{5 1}$

Charcoal lumps in black burned earth above pavement of building earlier than the wine magazine, from Area MZ-38-6. Comment: estimated to be earlier than the palace. $\mathrm{NaOH}$ pretreatment.

P-340. Southeast of Wine Magazine $\quad \mathbf{3 3 2 0} \pm \mathbf{5 7}$

Charcoal, earlier than wine magazine, but possibly contemporaneous with main building of the palace, from Area MZ-46. Comment: $\mathrm{NaOH}$ pretreatment.

P-326. Palace of Nestor, Main Building

$3450 \pm 65$

Charcoal from door jamb of SE door in Queen's hall. Middle of Late Helladic IIIB Period. Comment: some rootlets noted, all visible ones removed.

P-330. Palace of Nestor, Main Building $\quad \mathbf{3 3 6 0} \pm \mathbf{5 0}$

Charcoal from a horizontal beam above dado behind sentry stand, NE side of doorway leading from portico to vestibule of the Megaron. Middle of Late Helladic IIIB Period.

\section{P-329. Palace of Nestor, Main Building}

$3260 \pm 63$

Charcoal from horizontal beam above dado in $\mathrm{E}$ corner of inner portico of Propylon. Middle of Late Helladic IIIB Period. Comment: some rootlets noted, all visible ones removed.

\section{P-328. Palace of Nestor, Main Building}

$3220 \pm 64$

Charcoal from horizontal beam above dado in NE anta of portico of the Megaron. Middle of Late Helladic IIIB Period. Comment: some rootlets noted, all visible ones removed.

\section{P-332. Palace of Nestor, Wine Magazine}

$3140 \pm 61$

Charcoal (two samples combined) from W door jamb of door to vestibule, and from beam-slot in W wall of vestibule. Late in Late Helladic IIIB Period. Comment: $\mathrm{NaOH}$ pretreatment.

\section{P-341. Palace of Nestor, Workshop}

$3010 \pm 56$

Charcoal lumps, with red and black burned earth, debris from destruction of the palace. Late in Late Helladic IIIB Period. Comment: $\mathrm{NaOH}$ pretreatment.

\section{P-337. Northeast of Workshop}

$3030 \pm 61$

Charcoal, with debris fallen from NE wall of workshop, thrown down at time of destruction of the palace, from Area MY. Late in Late Helladic IIIB Period.

\section{Chios series, Greece}

This site is located near Emporio $\left(38^{\circ} 11^{\prime} \mathrm{N}\right.$ Lat, $26^{\circ} 03^{\prime} \mathrm{E}$ Long), on the E side of the southern tip of the island of Chios in the Aegean Sea. Excavations were carried on from 1952 to 1955 by the British School of Archaeol. at 
Athens under the directorship of M. S. F. Hood. Coll. 1954 by Hood; subm. 1959 by G. R. Edwards (Kohler and Ralph, 1961).

P-273. Early Bronze Age (Troy I) $\quad 3980 \pm 97$

Charcoal from remains of wooden beams in one room of a house at foot of hill in the Troy I settlement which was destroyed by fire. Sample found ca. $2 \mathrm{~m}$ below surface. Comment: $\mathrm{NaOH}$ pretreatment.

\section{P-292. Late Roman or Byzantine}

$920 \pm 44$

Charcoal lumps from bottom of concrete-lined cistern located inside the fortified Roman settlement on top of the Acropolis. Comment: half of sample was given usual acid pretreatment, while other half received additional $\mathrm{NaOH}$ pretreatment; difference in age was not significant, and counting runs were averaged.

\section{Tikal, Central America}

Tikal ( $17^{\circ} 13^{\prime} 18^{\prime \prime} \mathrm{N}$ Lat, $89^{\circ} 38^{\prime} 30^{\prime \prime} \mathrm{W}$ Long), in El Peten, Guatemala, is the site of extensive excavations and restorations of the Lowland Maya Classic period by the Univ. Mus., Univ. of Pennsylvania, in collaboration with the Govt. of Guatemala. The samples are presented in two series.

\section{Tikal Calendrical series}

This series is a collection of wood samples from vault and lintel beams from Temples I and IV, dated in an effort to confirm one of several conflicting hypotheses correlating dates of the Maya Long Count system with the Christian calendar. The samples were taken either from lintel beams bearing Maya dates, or from vault beams presumably set shortly after the placement of the lintel beams. All beam samples id. by G. K. Brizicky (S. J. Record Memorial Coll., School of Forestry, Yale Univ.) as zapote wood, Achras (Manilcara) sp., probably zapota L. (Manilcara zapotilla (Jacq.) Gilly), a member of the Sapotaceae family. A few samples, as noted, were given $\mathrm{NaOH}$ pretreatment, but no significant difference in age was noted. Most samples were riddled with termite holes, but all visible debris was removed except for test sample P-232. Coll. by Aubrey Trik, Proj. Architect, under direction of E. M. Shook, Field Director of the Tikal proj; subm. by Linton Satterthwaite, Curator of the Am. Sec., Univ. Mus., Univ. of Pennsylvania (Satterthwaite, 1956, 1958; Satterthwaite and Ralph, 1960). The reader is urged to consult the last reference cited for a fuller presentation of the correlation problem and of the dating results; dates B.P. listed there were calculated from A.D. 1960, and are changed below to refer to A.D. 1950.

The $\mathrm{C}^{14}$ dates for representative samples support some variant of the "11-16" (Goodman-Thompson-Martinez) "Correlation B" and excludes other proposals. The average results for five beams from Temple I and ten from Temple IV are as follows:

\begin{tabular}{ccc} 
Temple & $\mathrm{C}^{14}$ Dates & Correlation B Hypothesis \\
\hline I & A.D. $684 \pm 37$ & A.D. $695-712$ \\
IV & A.D. $746 \pm 34$ & A.D. $741-751$
\end{tabular}


These results are supported, that is, related to true ages, by the measurements of contemporaneous samples of known age (Ralph, 1961).

\section{P-229. Temple I, Vault Beam}

$$
1490 \pm 85
$$

Zapote wood from Vault Beam no. 1, Room 1, T-54. Comment: sample is presumed to have come from an older re-used beam since its age is significantly older than the average age $(1270 \pm 37$ в.P. $)$ of the other beams from Temple I.

\section{P-230. Temple I, Vault Beam}

$$
1300 \pm 93
$$

Zapote wood from Vault Beam no. 2, Room 1, T-55.

P-232. Temple I, Vault Beam

$$
1260 \pm 49
$$

Zapote wood from Vault Beam no. 2, Room 2, T-61. Comment: sample divided into two portions, termite debris removed from only one half; no significant difference in age, and counting runs were averaged.

P-234. Temple I, Vault Beam

$$
1260 \pm 56
$$

Zapote wood from Vault Beam no. 2, Room 3, T-68.

\section{P-247. Temple I, Lintel Beam}

$$
1270 \pm 49
$$

Zapote wood from Lintel no. 3, sec. $c$ or $d$, T-95.

P-251. Temple I, Lintel Beam

$1260 \pm 110$

Zapote wood from Lintel no. 3, sec. e, T-318.

\section{P-235. Temple IV, Vault Beam}

$1150 \pm 44$

Zapote wood from Vault Beam no. 1, Room 2, T-267.

P-236. Temple IV, Vault Beam

$1250 \pm 48$

Zapote wood from Vault Beam no. 2, Room 2, T-268.

P-237. Temple IV, Vault Beam

$1260 \pm 72$

Zapote wood from Vault Beam no. 3, Room 2, T-269.

P-238. Temple IV, Vault Beam

$1200 \pm 48$

Zapote wood from Vault Beam no. 4, Room 2, T-270.

P-242. Temple IV, Vault Beam

$1230 \pm 48$

Zapote wood from Vault Beam no. 1, Room 3, T-274.

P-243. Temple IV, Vault Beam

$1220 \pm 55$

Zapote wood from Vault Beam no. 2, Room 3, T-275.

P-244. Temple IV, Vault Beam

$1210 \pm 83$

Zapote wood from Vault Beam no. 3, Room 3, T-276.

P-245. Temple IV, Vault Beam

$1180 \pm 79$

Zapote wood from Vault Beam no. 4, Room 3, T-277. Comment: half of sample given usual acid pretreatment, while other half received additional 
$\mathrm{NaOH}$ pretreatment; no significant difference in age, and counting runs were averaged.

\section{P-248. Temple IV, Lintel Beam}

Zapote wood from Lintel no. 3, sec. $a, d$, or $f$, T-478.

P-249. Temple IV, Lintel Beam

$1210 \pm 48$

Zapote wood from Lintel no. 3, sec. $e$ or $g$, T-484. Comment: half of sample was given usual acid pretreatment, while other half received additional $\mathrm{NaOH}$ pretreatment; no significant difference in age, and counting runs were averaged.

\section{P-282. Temple IV, Lintel Beam}

$1310 \pm 44$

Zapote wood from Lintel no. 3, sec. $a$, T-579. Comment: sample was obtained for comparison purposes from the Mus. für Volkerkunde, Basel, Switzerland. Adjacent portion of this lintel was dated by Chicago (C-948, $1491 \pm 120$, Chicago V). The original lintel had been trimmed drastically for easier transport, and it may be assumed that both P-282 and C-948 were taken from older, but not necessarily the same, portions of this large beam. We believe that they were not representative of the time of inscription of the beam.

P-293. Structure 10

$\mathbf{1 3 4 0} \pm \mathbf{5 7}$

Zapote wood from beam in Am. Mus. of Nat. History, T-580. Comment: sample was taken for comparison with Columbia Univ. sample from adjacent point and intended to be a duplicate (L-113, $1479 \pm 120$ by solid carbon; $1504 \pm 60$ on recount of solid carbon converted to carbon dioxide; Lamont I; Broecker and others, 1959). The original lintel had been trimmed drastically for easier transport, and it may be assumed that both P-293 and L-113 were taken from inner and hence older portions of this large beam. For this reason we believe that they were not representative of the time of inscription of the beam.

\section{Tikal stratigraphic series}

This series was submitted for purposes of dating construction and ceremonial activity. The samples were collected in 1958 and 1959 in the Great Plaza-North Terrace-North Acropolis area of Tikal. Subm. by W. R. Coe, Univ. Mus., Univ. of Pennsylvania.

\section{Sample Group A}

P-285. Chultun 5D-5

$1970 \pm 44$

Chultun 5D-5, Great Plaza (Pl.5D-1), near NW corner of Temple I (Structure 5D-1). Flecks of charcoal scattered throughout earth and rubble filling chambers of chultun. Associated with sherds of Chicanel affiliation. Chultun sealed by earliest Great Plaza plaster floor, Pl.5D-1: Floor 5. The fill within the chambers could well have resulted from a relatively rapid redeposition of earth and occupation refuse. The laying of Floor 5 judged to have occurred no earlier than the result of $\mathrm{C}^{14}$ date-spread. Sample collected as 11D-Lot 20. 
P-286. Quarry 5D-1, North

$2100 \pm 45$

Quarry 5D-1, Great Plaza (Pl.5D-1), NW corner near NE corner of Temple II (Structure 5D-2). Flecks of charcoal scattered throughout layer of gritty silt overlying quarry bottom and E slope. Stratum believed to be waterlaid and to represent wash from early occupation in the Great Plaza area. Sherd material within this stratum is related to Chicanel. Stratum underlies stone fill of quarry, deposited in anticipation of laying of earliest plaza floor, PI.5D-1: Floor 5. Sample collected as 11D-Lot 29. Lies N of portion of same stratum that yielded P-287.

P-287. Quarry 5D-1, South

$2000 \pm 63$

Same provenience as that of P-286, but in S portion of exposed silt stratum. Sample collected as 11D-Lot 46.

P-288. Trench 9, North Terrace

$\mathbf{2 0 9 0} \pm \mathbf{5 5}$

Trench 9, North Terrace (Ter.5D-1); trench on N-S axis of Structure 5D-33. Flecks of charcoal in earth fill or accumulation underlying and sealed by PI.5D-1: Floor 5 and the earliest terraces, Ter.5D-1-8th and -7th. Sample is composite, comprising small charcoal collections from 12A-Lots 9, 10, and 13. Associated with ceramics related to Chicanel.

P-289. Trench 7, North Terrace

$\mathbf{2 0 4 0} \pm \mathbf{5 7}$

Trench 7, North Terrace (Ter. 5D-1) ; trench on N-S axis of Structure 5D-34. Flecks of charcoal in earth fill and accumulation, in part sealed by Ter.5D-1-7th and in part by a tamped marl plaza-based surface that turns up to Ter.5D-1-7th. Sample comprises small charcoal collections from 1A-Lots 18, 20, and 21. Associated with a small group of ceramics related to Chicanel.

General Comment on Group A (W.R.C.) : Pl.5D-1:Floor 5 is fully tied to Ter.5D-1-6th. The five samples come from materials deposited prior to or during the construction of PI.5D-1:Floor 5. Because of the strong possibility of redeposition, all charcoal samples in this series provide only maximum dates for the construction or deposition of whatever seals them. On this basis, Floor 5 of the Great Plaza may be concluded to have been laid no earlier than 1970 \pm 44 в.P. (P-285). Ter.5D-1-7th was built no earlier than $2040 \pm 57$ в.P. (P-289). As a point of reference, it should be noted that it is Ter.5D-1-2nd and Pl.5D-1:Floor 2 that relate to "Early Classic" monuments, the earliest yet found. On the whole, the series of dates shows that monumental construction in the immediate vicinity may have begun as early as the first century B.c. From the start, ceremonialism, judging from its architectural scale, was only slightly less elaborate than that of Late Classic times (ca. A.D. 600-900). The evident rapidity of rebuilding was unanticipated.

Sample Group B

\section{P-278. Room 3, Cache 19}

$1150 \pm 47$

Structure 5D-34, Room 3, central axis, Cache 19, an offering intrusive to the floor, and patch-sealed. Except for a few small sherds, cache was of ca. $5 \mathrm{lbs}$ of pure charcoal (representing twigs or small stems of pine, a grass of 
reed type, and hardwood not logwood or zapote). A lens of charcoal, comprising P-279, covered the cache patch and the floor about it. This lens turned up to a masonry altar containing the broken remains of Stela 26 . Collected as $12 \mathrm{C}$ Lot 13. Comment: half of sample was given usual acid pretreatment, while other half received additional $\mathrm{NaOH}$ pretreatment; no significant difference in age.

P-279. Room 3, Floor

$\mathbf{1 1 8 0} \pm \mathbf{5 5}$

See P-278. Charcoal, similar to P-278, sealed by collapsed masonry, overlying floor and Cache 19. Collected as 12C-Lot 3.

P-281. Room 3, Altar

$1530 \pm 52$

Structure 5D-34, Room 3, masonry altar, Stela 26, below butt of stela. Sample, small pieces of charcoal, could not be shown to have been sealed by the base of the stela, and, with its associated materials, may have been intruded during later disturbance of the altar. Collected as 12C-Lot 7.

P-284. Structure 5D

$\mathbf{1 5 5 0} \pm \mathbf{5 8}$

Structure 5D-34, interior of construction stage immediately underlying the building platform that sustains the building proper. Charcoal, perhaps a hearth, was concentrated in a small area in small pieces. Collected as 12C-Lot 22.

General Comment on Group B (W.R.C.) : the series itself, let alone the results of analysis, are problem-ridden. The building is ceramically late "Early Classic." Preliminary assessment of fill sherds would allow, in terms of the Uaxactun sequence, a date of ca. A.D. 400 (11.16 correlation). This estimate is supported by stratigraphically and typologically coeval discoveries in the North Acropolis, of which Structure 5D-34 is a frontal part. It is also suggestively confirmed by the date of P-284. The amount of evidently late disturbance encountered in the rooms of the temple must be fully evaluated before the $C^{14}$ dates of the other three samples can be appreciated.

\section{Sample Group $C$}

P-294. Structure 5D-23, Beam B-4

$\mathbf{1 3 5 0} \pm \mathbf{5 2}$

Structure 5D-23-1st, Room 3, Vault Beam B-4. Collected as field no. T-503.

P-295. Structure 5D-23, Beam B-8

$\mathbf{1 7 4 0} \pm \mathbf{5 0}$

Structure 5D-23-1st, Room 3, Vault Beam B-8. Collected as field no. T-504.

\section{P-296. Structure 5D-23, Beam B-14}

$1720 \pm 61$ T-505.

Structure 5D-23-1st, Room 3, Vault Beam B-14. Collected as field no.

General Comment on Group C (W.R.C.) : structure 5D-23-1st, the central of three western temples of the basically (in final form) "Early Classic" North Acropolis, was built on a floor that also sustains a building (Structure 5D-26lst) into which a tomb burial was set, with pottery vessels of Tzakol 2-3 affiliation, dated ca. A.D. 400 at Uaxactun. Both structures appear therefore to antedate the tomb. 
P-294 provides a date much too young if we assume that the vault beams were cut close to the date of their placement within the vault of the rear room of Structure 5D-23-1st. The remaining two samples yield results that, at first glance, seem too old. However, if the one-sigma allowance is added, the results are hardly out of line with an estimate of the age of the building, based upon the known stratigraphy of the North Acropolis. The problem remains, however, to rationalize the result of P-294.

\section{South America}

\section{P-345. Intihuasi Cave, Argentina}

$8060 \pm 100$

Bones, charred and partly charred, from Intihuasi Cave $\left(32^{\circ} 49^{\prime} 49^{\prime \prime} \mathrm{S}\right.$ Lat, $65^{\circ} 59^{\prime}$ W Long), Layers 3-4, Quadrant F3, San Luis Province, Argentina. Coll. 1951 and subm. 1959 by A. R. Gonzales, Cordoba Univ., Argentina (Gonzales, 1957). Comment: compare similar sample from same cave, Quadrant E4, dated by Yale (Y-228, $7970 \pm 100$, Yale III). In both cases, the associated material belonged to the Ayampitin Culture.

P-344. Alumbrera, Argentina

$1650 \pm 48$

Charcoal from Unidad Arqueologica D, no. 1, "Sitio Cubierto" (27 $38^{\prime}$ $5^{\prime \prime} \mathrm{S}$ Lat, 66 $6^{\circ}$ 55" W Long), near Alumbrera, Dept. of Andalgala, Catamarca Province, Argentina. Coll. 1958 and subm. 1959 by A. R. Gonzales (1959, 1960). Comment: compare with other samples from this site dated by Lamont (L-476A, $1530 \pm 100$, Lamont VII) and Yale (Y-558, $1630 \pm 60$, Yale V). Sample dates the Condorhuasi Culture that belongs, together with Barreales (P-343, this date list), to the early period of ceramic cultures of NW Argentina.

P-343. Guiyischi River, Site No. 13, Argentina $\quad 1210 \pm 54$

Charcoal from Site no. $13\left(27^{\circ} 10^{\prime} 22^{\prime \prime} \mathrm{S}\right.$ Lat, $67^{\circ} 18^{\prime} 33^{\prime \prime} \mathrm{W}$ Long), near Guiyischi River, Hualfin Valley, Dept. of Belen, Catamarca Province, Argentina. Coll. 1952 and subm. 1959 by A. R. Gonzales. Comment: site was a dwelling place of the Barreales culture with Cienega Polychrome pottery (Gonzales, 1957).

\section{E. Australia}

\section{Murray River Cave series, Australia}

Murray River Cave $\left(34^{\circ} 46^{\prime} \mathrm{S}\right.$ Lat, $139^{\circ} 36^{\prime} \mathrm{E}$ Long), is located at Fromm's Landing on the Murray River in South Australia (Ordnance Survey Renmark Sheet 254703; Lands Dept. Map Sec. 302, Hundred of Ridley, County of Sturt). The site is one of two large stratified Stone Age sites thus far excavated in Australia; the other, Devon Downs shelter, is ca. 5 mi downstream on the same river. Level IX at Devon Downs (L-271G, $4250 \pm 180$, Lamont III) has been typologically correlated with a Pirrian layer at Murray River Cave. The deposits at Murray River Cave extend beyond the earliest levels at Devon Downs, so the new site should produce the earliest date for an Australian site, with the exception of Tartanga (L-271E, $6020 \pm 150$, Lamont III). Coll. 1956 and subm. 1958 by D. J. Mulvaney, Univ. of Melbourne. 
P-308. Murray River Cave, Layer 6

$3750 \pm 85$

Ash and bits of shell, Sample no. 9 from Layer 6 (originally Layer V), collected from an area $\mathbf{l f t}$ square at depth of $7 \mathrm{ft} 4 \mathrm{in}$. Layer is characterized by a band of ash seen over the entire excavation; rock surface at rear of shelter at this level reddened by fire. Level is one of intense occupation, yielding one bone point, two crude microliths, and two flakes shaped like crude points but lacking obvious secondary trimming.

\section{P-309. Murray River Cave, Layer 8}

$\mathbf{3 8 7 0} \pm \mathbf{8 5}$

Charcoal and ash, Sample no. 14 from Layer 8 (originally Layer VIF), collected near rear of section at depth $10 \mathrm{ft}$ to $10 \mathrm{ft} 2 \mathrm{in}$. Between Layer 6 and this level were found: at $8 \mathrm{ft} 3$ in. jaw of extinct rat kangaroo (Bettangia pencillata); at $8 \mathrm{ft} 6 \mathrm{in}$. several bone points, including a "Mudukian" point, a possible broken Pirrian point, and three microlith flakes with retouch; at $9 \mathrm{ft}$ jaw of Sarcophilus cf. harrissi; at $9 \mathrm{ft} 10 \mathrm{in}$. a very fine geometric quartz microlith.

\section{P-311. Murray River Cave, Layer 9}

$4050 \pm 85$

Wood charcoal and ash, Sample no. 17 from Layer 9 (originally Layer VIi), collected from $11 \mathrm{ft} 1$ in. to $11 \mathrm{ft} 4$ in. At $11 \mathrm{ft} 10$ in. to $12 \mathrm{ft}$, a geometric microlith was found; this was the deepest artifact level in this part of the cave, although smoke-black on uncovered rear wall indicates presence of fires down to level of $13 \mathrm{ft}$. Comment: two other samples, bracketing the dates listed above, were dated by the New Zealand laboratory in 1960: Layer 4, NZ R-456/2, $3240 \pm 80$; and Layer 10, NZ R-456/1, 4850 \pm 100 (Mulvaney, 1961).

Date lists:

\section{REFERENCES}

British Museum II

Chicago V

Lamont I

Lamont III

Lamont VII

New Zealand III

Pennsylvania III

Yale III

Yale V

Barker and Mackey, 1960

Libby, 1954

Kulp, Feely, and Tryon, 1951

Broecker, Kulp, and Tucek, 1956

Olson and Broecker, 1961

Fergusson and Rafter, 1957

Ralph, 1959

Barendsen, Deevey, and Gralenski, 1957

Stuiver, Deevey, and Gralenski, 1960

Barendsen, G. W., Deevey, E. S., and Gralenski, L. J., 1957, Yale natural radiocarbon measurements III: Science, v. 126, p. 908-919.

Barker, H., and Mackey, C. J., 1960, British Museum natural radiocarbon measurements II: Am. Jour. Sci. Radioc. Supp., v. 2, p. 26-30.

Broecker, W. S., Kulp, J. L., and Tucek, C. S., 1956, Lamont natural radiocarbon measurements III: Science, v. 124, p. 154-165.

Broecker, W. S., Olson, E. A., and Bird, J., 1959, radiocarbon measurements on samples of known age: Nature, v. 183, p. 1582-1584.

Caskey, J. L., 1960, The earliest settlements at Eutresis; supplementary excavations, 1958: Hesperia, Jour. Am. School of Classical Studies at Athens, v. 29, p. 126-167.

Coon, C. S., 1957, The seven caves: New York, Knopf, p. 290-294.

Craig, Harmon, 1961, Mass-spectrometer analyses of radiocarbon standards: Radiocarbon, v. 3 , p. $1-3$.

Fergusson, G. J., and Rafter, T. A., 1957, New Zealand ${ }^{14} \mathrm{C}$ age measurements-3: New Zealand Jour. Sci. and Technology, sec. B, v. 38, n. 7, p. $732-749$. 
Gonzales, A. R., 1957, Dos fechas de la cronologia arqueologica Argentina obtenidas por el metodo de radiocarbon: Univ. Nac. del Litoral [Rosario, Argentina], Inst. de

Antropologia, $19 \mathrm{p}$.
1959, Nuevas fechas de la cronologia arquelogica Argentina obtenidas por el metodo de radiocarbon (II) : Cien. e Inv., v. 15, n. 6, p. 185-190.

1960, Nuevas fechas de la cronologia arquelogica Argentina obtenidas por el metodo de radiocarbon (III) : Cien. e Inv., v. 16, n. 4, p. 142-145.

Kohler, E., and Ralph, E. K., 1961, $\mathrm{C}^{14}$ dates for sites in the Mediterranean area: Am. Jour. Archaeology, v. 65, p. 357-367.

Kulp, J. L., Feely, H. W., and Tryon, L. E., 1951, Lamont natural radiocarbon measurements I: Science, v. 114, p. 565-568.

Libby, W. F., 1954, Chicago radiocarbon dates V: Science, v. 120, p. 733-742.

Mulvaney, D. L., 1961, Australian radiocarbon dates: Antiquity, v. 35, n. 137, p. 37-39.

Olson, E. A., and Broecker, W. S., 1961, Lamont natural radiocarbon measurements VII: Radiocarbon, v. 3, p. 141-175.

Ralph, E. K., 1959, University of Pennsylvania radiocarbon dates III: Am. Jour. Sci. Radioc. Supp., v. 1, p. 45-58.

1961, Radiocarbon "effective" half-life for Maya calendar correlations: Amer. Antiquity, v. 27, p. 229-230.

Richards, H. G., 1931, The subway tree-a record of a Pleistocene cypress swamp in Philadelphia: Bartonia, n. 13, p. 1-6.

1960, The date of the "subway tree" of Philadelphia: Penn. Acad. Sci. Proc.,

v. 34, p. 107-108.
Satterthwaite, Linton, 1956, Radiocarbon dates and the Maya calendar correlation problem: Amer. Antiquity, v. 21, p. 416-419.

1958, Comment on Thompson's paper: Pan-Amer. Union, Soc. Sci. Mon. 5, p. 53.57.

Satterthwaite, L., and Ralph, E. K., 1960, New radiocarbon dates and the Maya correlation problem: Amer. Antiquity, v. 26, p. 165-184.

Stuiver, M., Deevey, E. S., and Gralenski, L. J., 1960, Yale natural radiocarbon measure. ments V: Am. Jour. Sci. Radioc. Supp., v. 2, p. 49-61. 